\title{
Observation of Baillon's Crake (Zapornia pusilla) in Oomayampatti Lake the first record for Namakkal District, Tamil Nadu, India
}

\section{Siva T., Sathyamoorthy S., Mahendiran Mylswamy, Goldin Quadros*}

Wetland Ecology Division, Sálim Ali Centre for Ornithology and Natural History, Anniakatty, Coimbatore, 641108, India

Documentation of biodiversity along the wetlands is one of the first steps towards conservation of an ecosystem. Avifauna is the most charismatic taxa that have been the subject of interest for researchers, naturalist to nonprofessional. Observation of birds in their natural habitat can help in bringing forth several concerns associated with the ecology of the landscape. Hence, based on the Wetland Rules 2010 \& 2017, during our study to prioritize the wetlands from Tamil Nadu state for conservation, we included the documentation and distribution of birds as one of the important criteria. It was during our field surveys in Namakkal district on 28th February 2018 at 12.30 noon, we observed the Baillon's Crake Zapornia pusilla amidst the marshes of the Oomayampatti Lake (Plate-1a,b). Oomayampatti Lake is located in the village of Oomayampatti in Namakkal District of Tamil Nadu India, at an altitude of 217 meters. The lake is dominated by Prosopis juliflora and Ipomoea plant species. The water from the wetland is mostly used for agriculture and by the domestic cattle. The Lake is seasonal, mostly dependant on the rainfall and is spread over an area of 131 hectares, during ourvisit the lake was $70 \%$ dry. In the marshy region of the lake where there was still some water amidst the thicket of Prosopis, we saw a bird searching for food. On closer observation and photographing the bird, we identified the bird as Baillon's crake Zapornia pusilla (Earlier, it was included under the genus Porzana (BirdLife International 2018; http://www.birdlife.org on 26/04/2018). The bird was observed to have rufous brown upperparts with extensive white markings, and buff underparts. It's beak and feet were completely green and the underparts had extensive barring, which extended down the flanks right up to the legs. The identification was further conf irmed by Ali (1941) and Grimmett et al. (2011).

Baillon's crake a Schedule IV species under the Indian Wildlife Protection Act 1972 is categorized as Least Concern by the International Union for Conservation of Nature (IUCN, 2017; www.iucnredlist.org). The Baillon's Crake is a solitary, very shy small water bird belonging to
Study Area: Oomayampatti Lake

Coordination: $11^{\circ} 29 \cdot 51.66$ " N; $70^{\circ} 01.18 .48$ "E

Key words: Wetlands, Avifauna, Rallid species, Migratory

family Rallidae and occurs either singly or in pairs (Ali \& Ripley 1987, BirdLife International 2018; http://www.birdlife.org on 26/04/2018). In India, it is normally found along freshwater wetlands, marshes, along the edges of lakes and ponds, dense reeds and grasses and among paddy fields (Ali \& Ripley, 2001; Kazmierczak, 2000; Grimmett et al. 2011; Rasmussen \& Anderton 2012). Baillon's Crake is a widespread rallid species where the European and Asian populations appear to be fully migratory (BirdLife International, 2018; http://www.birdlife.org on 26/04/2018). It breeds in the Indian Himalayas (Grimmett et al., 2011). It is a passage migrant in the rest of the country during the winter (Kazmierczak, 200o). There are mostly scattered individual records of sighting from the Indian mainland (Grimmett et al., 2011).

To assess the distribution, we conducted an extensive literature survey for the species and found a number of recordings from the Northern states of the country where it is known to breed. In Tamil Nadu, we could get only one published literature by Samuel (2013) for the observation of the Baillon's crake in Thenneri Lake, near Chennai during March 2012. Hence, we collated data from the ebird web portal where the observations of the Baillon's crake are reported by naturalist since 2008 . We compiled the data and found observations reported from 38 different wetland locations spread across 19 districts in Tamil Nadu (Table-1). We also compiled the monthly observations from 2008 to February 2018 and found that the bird was reported a maximum number of times during the month of February (Fig.-1). Further, from the compiled secondary sources, we did not find any information, literature or records for the Namakkal District. This finding makes our observation in Oomayampatti lake the first record for the Baillon's crake (Zapornia pusilla) for Namakkal district of Tamil Nadu. .

Acknowledgements:

The authors wish to thank the Funding agency namely the Tamil Nadu State Planning Commission - Land Use Division and the Tamil Nadu State Forest Department for assigning the project to SACON. Director SACON is also kindly acknowledged for his

*Corresponding Author: goldinq@gmail.com 
NOTES ON NATURAL HISTORY

110:(3) 224-225..

Table 1: Baillon's Crake Sighting reported in Different Districts of Tamil Nadu with Maximum number of Birds (MB) \& Number of Checklist observations (NB)

\begin{tabular}{|c|c|c|c|c|}
\hline S. Districts & Year, Month & Name of the Wetland/ & M & $\mathrm{N}$ \\
\hline \multicolumn{2}{|l|}{$\bar{N}$. } & Place & B & $\mathrm{B}$ \\
\hline 1 Ariyalur & 20o8, Feb. & Karaivettai Bird Santuary & 1 & 1 \\
\hline 2 Chennai & 2015, Jan. & Theosophical Society & 1 & 1 \\
\hline & 2017, Feb. & Chennai & 2 & 1 \\
\hline & 2018, Feb. & Kaiveli & 1 & 1 \\
\hline 3 Coimbatore & 2017, Jan., Feb., & Muthukoundanputhur & & \\
\hline & Nov., Dec. & Kulam & 1 & 2 \\
\hline & & Kannampalayam Lake & 1 & 1 \\
\hline & & Krishnampathi Lake & 2 & 9 \\
\hline Kanchipura & $2016, \mathrm{~J}$ & Sholinganallur, & & 16 \\
\hline
\end{tabular}

Mar., Oct., Nov., Nathapettai Lake,

Dec. Uthukadu Lake,

Thenneri Lake

2017, Jan., Feb., Pallikaranai Marshland, 1243

Mar., Apr., Dec. Chitlapakkam Lake,

Sholinganallur,

Nathapettai Lake,

Uthukadu Lake

2018, Jan., Feb. Pallikaranai Marshland,

Sholinganallur

5 Krishnagiri 2017, Dec. Avathanapatti Lake

6 Madurai 2014, Feb. Kilangkulam

2018, Jan. KarisalKulam

7 Pudukottai 2017, Nov. AdappanKulam

2018, Jan. Ammapattnam

8 Salem

2014, Dec.

Kannankurichi Lake

2015, Jan.-Mar.

2016, Jan., Feb.,

Nov., Dec.

2017,Jan.-Apr. Kannankurichi Lake,

Nov., Dec. Pavalathanoor Lake

2018, Jan-Apr. Kannankurichi Lake $\quad 6 \quad 19$

9 Sivaganga 2016, Feb. Vettangudi Bird Sanctuary $\quad 1 \quad 1$

2017, Jan. Keelanettur Tank $\quad 1 \quad 1$

2015, Feb. Mittanamalli 11

2016 Korattur Lake $\quad 2 \quad 2$

2017, Dec. Nayapakkam $\quad 1 \quad 1$

2018, Jan.-Mar. Korattur Lake, Nayapakkam2 7

11 Thoothu- 2018, Jan. Arumugamangalam Lake 11

kkudi

12 Tiruchira- 2016, '17, '18 National Institute of $4 \begin{array}{ll}4 & 14\end{array}$

ppalli Jan-Apr., Dec. Technology

13 Tirunelveli 2017, Jan., Mar. Elandakulam,

Naranammalpuram

14 Tiruppur 2017, 2018

Koolipalayam Reservoir

15 Tiruvanna- 2017, Feb.

Kilnathur Lake

$\begin{array}{lll}\text { Udayamarthandapuram } & 1 & 1\end{array}$

16 Tiruvarur 2016, Feb.

Bird Sanctuary

17 Vellore 2017, Feb. Alamelumangapuram $\quad \begin{array}{llll}1 & 1\end{array}$

18 Villupuram 2017, Nov., Feb. Kaliveli Lake, Ottai Lake 23

2018, Jan. Kaliveli Lake $\quad 4 \quad 2$

19 Virudunagar 2016, Nov. Kondaneri Lake $\quad 2 \quad 1$

2017, Jan. $\quad \begin{array}{lll}1 & 1\end{array}$

2018, Feb. Kullursandai Reservoir $\quad 1 \quad 1$

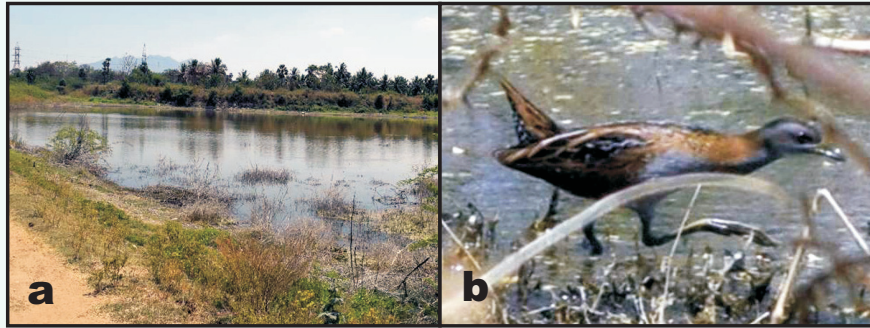

Plate-1: a) Environmental setting of Oomayampatti Lake; b) Baillon's Crake in Oomayampatti Lake

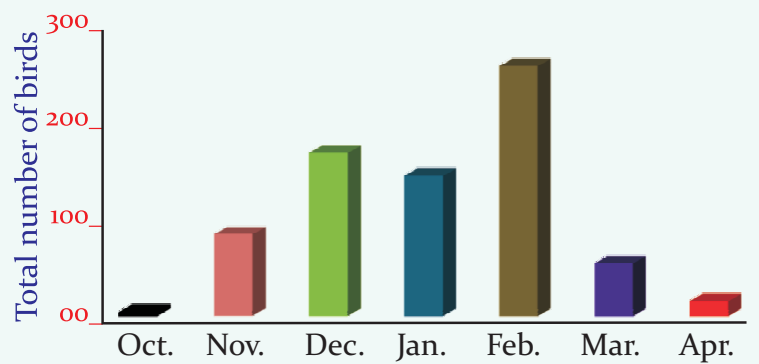

Figure- 1: Total Number of birds observed in different months across Tamil Nadu from 2008 to February 2018.

constant support and encouragement.

References:

Ali, S. (1941): The Book of Indian Birds. Pub. by: Oxford University Press, Mumbai, India. P. 131.

Ali, S. \& Ripley, S.D. (2001): Handbook of the birds of India and Pakistan together with those of Bangladesh, Nepal, Bhutan and Sri Lanka. 2nd edition Delhi: (Sponsored by Bombay Natural History Society.) Pub. by: Oxford University Press.

Grimmett, R., Inskipp, C. \& Inskipp, T. (2011): Birds of Indian Subcontinent. Pub. by: Princeton University Press, India. P. 528.

Kazmierczak, K. (2000): A Field Guide to the Birds of India, Sri Lanka, Pakistan, Nepal, Bhutan, Bangladesh and the Maldives. Pub. by: Pica Press, United Kingdom. P. 108.

Rasmussen, P.C. \& Anderton, J.C. (2012): Birds of South Asia: the Ripley guide. 2nd ed. Pub. by: Smithsonian Institution and Lynx Edicions. Washington, D.C. and Barcelona. 2 volumes; P. 378 \& 683.

Samuel, J. (2013): Sighting of Baillon's Crake Porzana pusilla near Chennai, India. J. Bombay Nat. Hist. Soc., 